\title{
EVALUATION OF THREE WILD SPECIES OF ALMOND ON THE BASIS OF THEIR MORPHOLOGICAL CHARACTERS
}

\section{B. BANINASAB ${ }^{A, C}$ and M. RAHEMI ${ }^{B}$}

\author{
A Department of Horticulture, College of Agriculture, Isfahan University of \\ Technology, Isfahan 84154, Iran \\ ${ }^{B}$ Department of Horticulture, College of Agriculture Shiraz University, Shiraz, Iran \\ cCorresponding author e-mail: bbanin@cc.iut.ac.ir \\ Telephone number: +98-311-3913415, Fax number: +98-311-3912254
}

Manuscript received: June 20, 2006; Reviewed: January 29, 2007; Accepted for publication: January 29, 2007

\begin{abstract}
Due to the suitable climatic conditions, Iran is one of the most important growing centre for wild and domesticated species/varieties of almond. Because of the adaptability of wild almond species to severe environmental conditions and resistance to drought, salinity and some pest and diseases, these can be used as rootstock for almond cultivars and in breeding programs for rootstock improvement in Iran. In this study, seeds of Amygdalous scoparia, A.webbii and A. orientalis were planted. The analysis of variance showed a significant difference between species. However, A. scoparia had highest stem height and leaf length. At the end of the experiment, the thickest stems were developed by A. scoparia, whereas the thinnest stems by A. orientalis. A. webbii produced more number and longer roots per seedling than the other two species. The correlation between various morphological traits showed that a few shoot characters were significantly correlated with root traits. However, leaf length, leaf width, leaf area, root number and root diameter for P. webbii, and leaf number, leaf length, leaf width, petiole length and root number characters for P.scoparia, and stem height, leaf number, leaf length, petiole length, internode length and root number for P. orientalis were found to be important morphological traits to evaluate seedling charactristics of wild almond genotypes before their nursery test.
\end{abstract}

KEYWORDS: Morphological attributes, Prunus webbii, P. scoparia, P. orientalis. 


\section{INTRODUCTION}

The cultivated almond (Prunus amygdalus Batsch) belongs to Rosaceae family, subfamily Prunoideae, and typified by a drupe fruit structure [8]. Wild populations of almond species representing a wide range of morphological and geographical forms have evolved throughout southwest and central Asia from Turkey and Syria into the Caucasus Mountains, through Iran, and into the deserts of Tian-Shan and Hindu Kush Mountains of Tadjikystan, Uzbckistan, and Afghnistan [2, 3, 5, 9]. Over 30 species have been described by botanists may represent subspecies or ecotypes within a broad collection of genotypes which are adapted to a range of ecological niches in the deserts, steppes, and mountains of central Asia [8].

Kester and Gradziel [8] reported that immense possibilities exist for rootstock improvement through the use of other almond species either by direct selection within the species or by their hybridization with cultivars almond. The wide genetic diversity present among related almond species provides an enlarged pool of available germplasm that has not been sufficiently exploited [7]. These group of related species provide a potential source of variability including hardiness and late bloom (e.g., P. webbii, P.bucharica), self-fertility (P.webbii, P.mira), modified growth habit and tree size (P.webbii, P.argentea) but they might be expected to result in combinations of genes with unexpected phenotypic expressions [9]. Vlasic [11] concluded that the sources of drought tolerance may come from other almond species which are highly xerophytic including P.webbii. P. webbii can be used as a rootstock for almond, nectarine and peach $[1,6]$. According to Dimitrovski and Ristevski [6] P. webbii is dwarf rootstock for cultivated almond. They reported that, seedlings of P.webbii made 30-50\% less growth than those of P.amygdalus and almond cvs grafted on P.webbii showed a similar reduction in vigor. Chilling as expressed by vegetative bud break in relation to flowering may also be a useful indicator of rest requirement [8]. P.orientalis plants leaf out later than the opening of flowers and this trait may be associated with increased tolerance to blossom freezing [4].

For rootstock production, reliable seed materials with fast seedling growth are required in the nursery. Since Iran is extremely rich in wild almond tress, finding such seed materials should not be difficult. These species can be used as a rootstock for almond after testing their effects on the scion productivity, nut quality and their tolerance to soil-borne diseases.

There is no study in the literature demonstrating variation of seedling characteristics of wild almond species. Therefore, this study aims to evaluate seedling behavior of P.orientalis, P.webbii and P.scoparia at the inter- specific level.

\section{MATERIALS AND METHODS}

Seeds of P.orientalis, P.webbii and P.scoparia were obtained from the Research Centre of Natural Resources and Animal Science at Shiraz. Sound seeds of all species were mechanical scarified and then soaked in water for $48 \mathrm{~h}$. The nuts were mixed with peat-moss [3:1, peatmass:seed $(\mathrm{V} / \mathrm{V})]$ and stratified at $4 \pm 1^{\circ} \mathrm{C}$ for 30 days. After stratification, nuts were sown directly in $5 \mathrm{~kg}$ black plastic bags filled with a $1: 1: 1(\mathrm{~V} / \mathrm{V})$ mixture of fine sand, leaf mould and soil. The bags were then transferred to the glasshouse, with an average temperature of 29.8 $\pm 5^{\circ} \mathrm{C}$ under natural photoperiod for the whole period of the experiment. The experiment was arranged in a completely randomized design with ten replications and five plants per replication. Four months after sowing, seedlings were removed from the containers and the root system was carefully washed for the removal of media and following observations were recorded. Table 1 enlist the traits surveyed in this study.

Correlations were performed between morphological traits of the seedling characteristics of each species.

The data was statically analysed and the mean were compared using Duncan's Multiple Range Test (DMRT). Data recorded as percentage were analysed after appropriate statistical transformation. Correlation coefficients among morphological traits were calculated using the SAS package program.

\section{RESULTS AND DISCUSSION}

The analysis of variance showed a significant difference among species for most of the traits measured. Differences for most traits showed high genetic variability among these species. Therefore, this genetic variability can be used either in rootstock selection or rootstock breeding programs. Tables 2 and 3 shown comparison of means of shoot and root traits measured of all species, respectively.

The stem height was not significantly different between P.scoparia and P.orienatlis, whereas the differences were significant between these two species and P.webbii (Table 2). However, at the end of the study, P.scoparia had the tallest $(20.58 \mathrm{~cm})$, and P.webbii the shortest stem $(14.88 \mathrm{~cm})$ (Table2). These results are in agreement with Dimitrovski and Ristevski [6] who found that P.webbii was dwarfing rootstock for cultivated almond.

Another character to be taken into consideration was the tree growth capacity, as determined by stem diameter. Stem diameter, which is essential to allow early budding 
Table 1: The list of traits and their measures

\begin{tabular}{ll}
\hline \multicolumn{1}{c}{ Traits } & Character measures \\
\hline Shoot characters & From soil level to the terminal meristem \\
Stem height $(\mathrm{cm})$ & At the most diameter of stem \\
Stem diameter $(\mathrm{mm})$ & The distance between the two node in middle of stem \\
Internode length $(\mathrm{mm})$ & \\
Shoot fresh weight $(\mathrm{g})$ & \\
Shoot dry weight $(\mathrm{g})$ & Determined after $72 \mathrm{~h}$ of drying at $70^{\circ} \mathrm{C}$
\end{tabular}

Leaf characters (four leaves were collected from the mid-shoot portion and used for measurement)

Leaf number

Leaf length (mm)

From the base of petiole to the tip of blade

Leaf width (mm)

At the widest part of blade

Leaf area $\left(\mathrm{mm}^{2}\right)$

Using the leaf area meter

Petiole length (mm)

From the base of petiole to starting point of blade

\section{Root characters}

$\left.\begin{array}{l}\text { Root length }(\mathrm{mm}) \\ \text { Average root diameter }(\mathrm{mm}) \\ \text { Root number } \\ \text { Root fresh weight }(\mathrm{g}) \\ \text { Root dry weight }(\mathrm{g})\end{array}\right\}$

Using the Delta- T SCAN image analysis system

and transplanting in to orchard. Differences in stem diameter were observed among the species (Table 2). The thickest stems were developed by P.scoparia $(1.83 \mathrm{~mm})$, whereas the thinnest stems were measured in P.webbii and P.orieantalis (1.40 and $1.30 \mathrm{~mm}$, respectively) (Table 2). Emergence time of the species grown in the greenhouse may affect seedling growth. In this experiment, we observed emergence in P.scoparia was earliest than the other species. Such a difference might explain the season for better stem height and diameter of P.scoparia than the other species. The reasons for the differences in stem diameter might be controlling other genetic factors responsible for seedling growth. There is no report in the literature on stem diameter of these species. The leaf number and petiole length of P.orientalis were more and large (33.88 and $2.75 \mathrm{~mm}$, respectively) followed by P.scoparia and P.webbii (Table 2). Although, P.webbii produced seedlings with less leaves, but the leaf length, 


\section{B. BANINASAB and M. RAHEMI}

Table 2: Comparison of means of shoot traits measured in wild almonds species.

\begin{tabular}{lccc}
\hline Trait & P. orientalis & P. scoparia & P. webbii \\
\hline Stem height $(\mathrm{cm})$ & $19.10 \mathrm{a} *$ & $20.58 \mathrm{a}$ & $14.88 \mathrm{~b}$ \\
Stem diameter $(\mathrm{mm})$ & $1.30 \mathrm{~b}$ & $1.83 \mathrm{a}$ & $1.40 \mathrm{~b}$ \\
Leaf number & $33.88 \mathrm{a}$ & $29.15 \mathrm{~b}$ & $25.13 \mathrm{c}$ \\
Leaf length $(\mathrm{mm})$ & $27.63 \mathrm{~b}$ & $32.83 \mathrm{a}$ & $34.10 \mathrm{a}$ \\
Leaf width (mm) & $7.88 \mathrm{ab}$ & $5.90 \mathrm{~b}$ & $14.25 \mathrm{a}$ \\
Leaf area (mm $\left.{ }^{2}\right)$ & $125.00 \mathrm{~b}$ & $147.30 \mathrm{~b}$ & $309.80 \mathrm{a}$ \\
Petiole length $(\mathrm{mm})$ & $2.75 \mathrm{a}$ & $2.50 \mathrm{a}$ & $1.30 \mathrm{~b}$ \\
Internode length $(\mathrm{mm})$ & $11.38 \mathrm{a}$ & $9.90 \mathrm{a}$ & $9.83 \mathrm{a}$ \\
Shoot fresh weight $(\mathrm{g})$ & $0.55 \mathrm{a}$ & $0.65 \mathrm{a}$ & $0.49 \mathrm{a}$ \\
Shoot dry weight $(\mathrm{g})$ & $0.13 \mathrm{a}$ & $0.11 \mathrm{a}$ & $0.13 \mathrm{a}$
\end{tabular}

* In each row or column, means with the similar letters are not significantly different at $1 \%$ level of probability using DMRT.

Table 3: Comparison of means of root traits measured of wild almonds

\begin{tabular}{lccc}
\hline Trait & P. orientalis & P. scoparia & P. webbii \\
\hline Root length $(\mathrm{mm})$ & $231.30 \mathrm{~b} *$ & $235.00 \mathrm{~b}$ & $407.20 \mathrm{a}$ \\
Average Root diameter $(\mathrm{mm})$ & $1.06 \mathrm{a}$ & $1.05 \mathrm{a}$ & $0.87 \mathrm{a}$ \\
Root number & $16.00 \mathrm{~b}$ & $15.07 \mathrm{~b}$ & $37.42 \mathrm{a}$ \\
Root fresh weight $(\mathrm{g})$ & $0.17 \mathrm{~b}$ & $0.19 \mathrm{~b}$ & $0.28 \mathrm{a}$ \\
Root dry weight $(\mathrm{g})$ & $0.02 \mathrm{~b}$ & $0.02 \mathrm{~b}$ & $0.04 \mathrm{a}$ \\
\hline
\end{tabular}

* In each row or column, means with the similar letters are not significantly different at $1 \%$ level of probability using DMRT.

width and area $\left(34.10 \mathrm{~mm}, 14.25 \mathrm{~mm}\right.$ and $309.80 \mathrm{~mm}^{2}$, respectively) were larger than the other species (Table 2). Leaf characters of P.scoparia and P.oreintalis were similar to there reported by Sabeti [10] and Zeinalabedini et al. [12].

In this study differences among fresh and dry weight of shoot of the species were not significant (Table 2). However, shoot fresh weight and dry weight were greatest in P.scoparia (Table 2).

The characters of root system have also been determined. The results showed that P.webbii seedlings had more, larger and greater fresh and dry weights of root system (37.42, $407.20 \mathrm{~mm}, 0.28 \mathrm{~g}$ and $0.04 \mathrm{~g}$, respectively) than the other two species (Table 3). There is no report in the literature on root system of species, and our study shows that there is a variation between the three species with regard to these important traits.

The correlations between pair of traits are shown separately for each species (Tables 4, 5 and 6). Several shoot characters were significantly correlated with root characters. In P.webbii, stem diameter was significantly correlated with leaf number, leaf length and root number. This might be due to the role of the leaf in carbohydrate synthesis and root in the absorption of water and mineral salts. Root diameter was significantly correlated with leaf length, leaf width and leaf area and negatively with shoot 


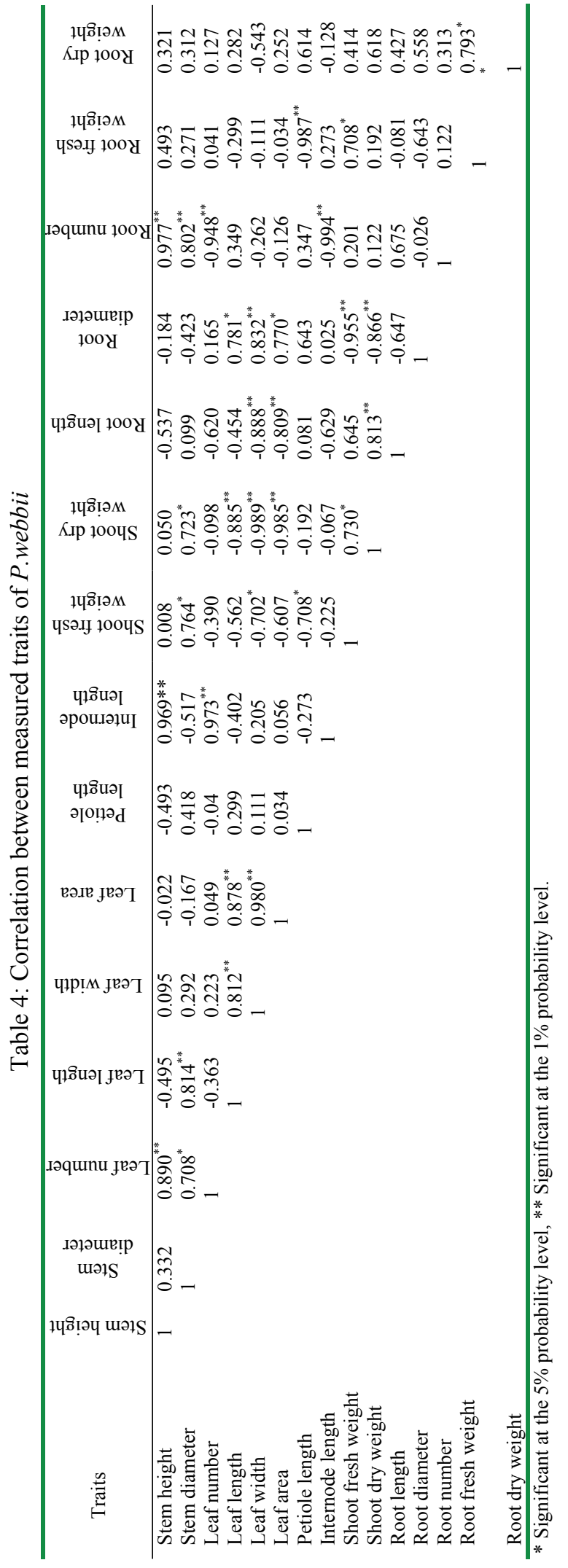

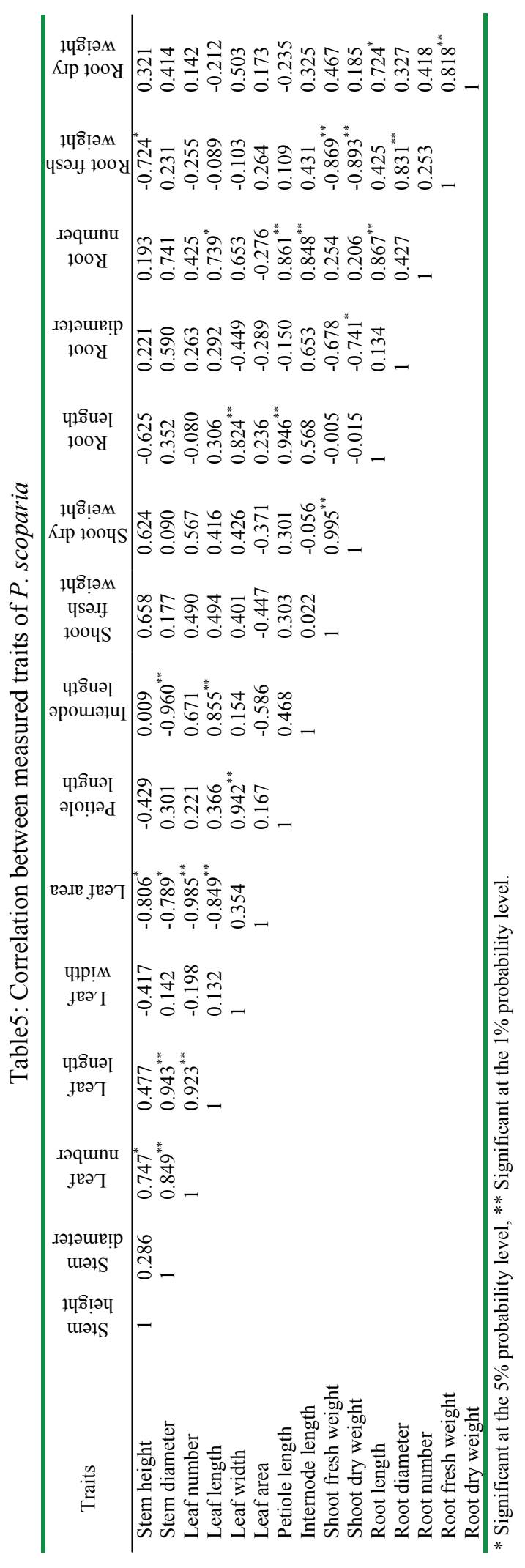




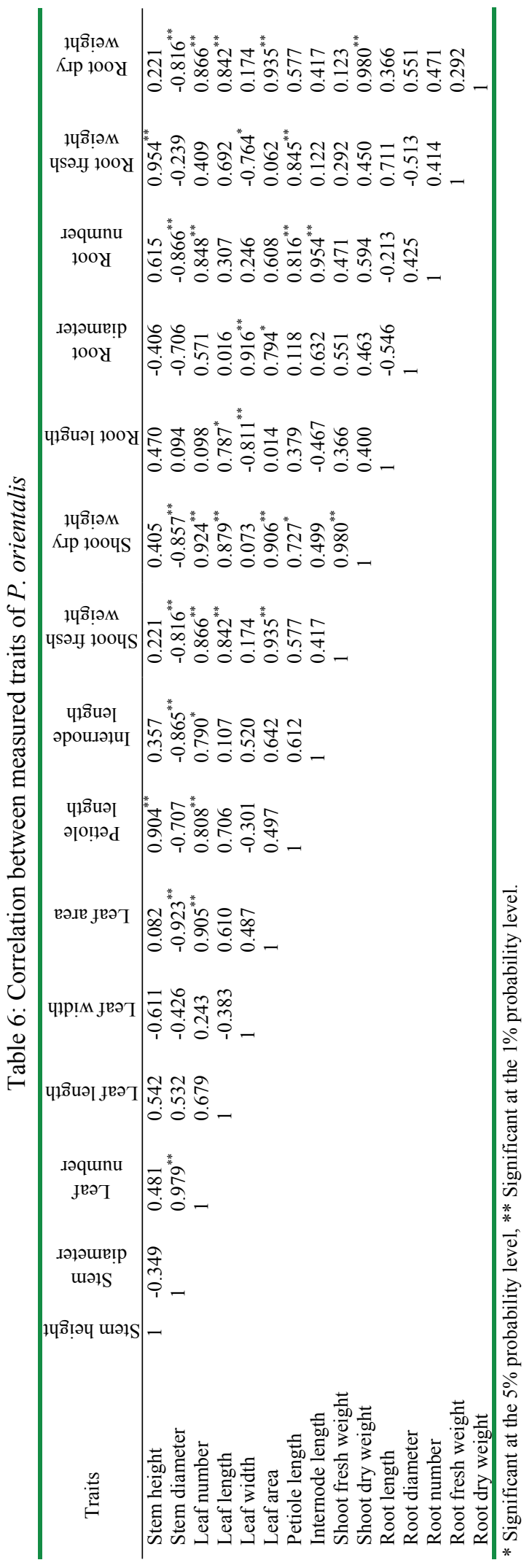

fresh and dry weights (Table 4). In P.scoparia, root length was significantly correlated with leaf width and internode length. Root number was significantly correlated with leaf length, petiole length, internode length and root length (Table 5). In P.orientalis, stem diameter was significantly correlated with leaf number and negatively with leaf area, internode length, shoot fresh weight, shoot dry weight, root number and root dry weight (Table 6).

These correlations suggest that many of the associations between morphological traits of shoot and root vary between these three species. However, leaf length, leaf width, leaf area, root number and root diameter for P.webbii, and Leaf length and width, petiole length and root number characters for P.scoparia and stem diameter, leaf number, leaf length, petiole length, internode length and root number for P.orientalis were found to be important morphological traits to evaluate seedling characteristics of almond genotype before nursery test.

\section{REFERENCES}

[1] Alberghina O., The wild almond, Amygdalus webbii, of southwest Sicily, Tecnica- Agricoia (1978) 30: 385-393.

[2] Browicz K., Amygdalus L., in: Rechinger K., H. (Eds.), Flora Iranica, Akademische Druck- U. Verlagsanstalt, Graz, 1969, pp. 166-168.

[3] Browicz K., Zohary D., The genus Amygdalus L. (Roseaceac): Species relationships, distribution and evolution under domestication. Genet. Reso, Crop Evol.(1996) 43: 229-247.

[4] Buyukilmaz M., Kester D. E., Comparative hardiness of flower buds and blossoms of some almond genotypes in relation to time of bloom and leafing, J. Amer. Soc. Horti. Sci. (1976) 101: 344-347.

[5] Denisov V. P., Almond genetic resources in the USSR and their use in production and breeding, Acta Horti. (1998) 224: 299-306.

[6] Dimitrovski T., Ristevski B., Investigation on the suitability of the wild almond, Amygdalus webbii, as a rootstock, Jugoslovensko-Vocarstvo (1973) 6: 15-21.

[7] Grasselly C., Reflexions sur les caracteristique des especes sauvages d'amygdalus et sur leur utilisation eventuelle dans des programmes d'amelioration genetic, 3rd Colloque GREMPA, CIHEAM, Bari, Italy, (1977): 70-77.

[8] Kester D. E., Gradiziel T. M., Almonds, in: Janick J., Moore J. N. (Eds.), Fruit Breeding. Vol. III. Nuts, John Wiley and Sons, New York, 1996, pp. 1-97.

[9] Kester D. E., Gradziel T. M., Grasselly C., Almond (Prunus), in: Moore J. N., Balligton I. R. (Eds.), 


\section{EVALUATION OF THREE WILD SPECIES OF ALMOND ON THE BASIS OF THEIR MORPHOLOGICAL CHARACTERS}

Genetic Resources of Temperate Fruits and Nut Crops, International Society Horticultural Science, Wageningen, 1990, pp. 701-758.

[10] Sabeti H., Forests, Trees, and Shrubs of Iran, Iran University of Science and Technology Press, Tehran, 1994.

[11] Vlasic A., L'amygdalus webbii Spach edi soulsi ibridi col pesco come portaninnestro del mandorlo, $3 \mathrm{rd}$
Colloque GREMPA, CIHEAM, Bari, Italy, (1977): 8081 .

[12] Zeinalabedini M., Grigorian V., Valizadeh M., Moghaddam M., Modares Hashemi, S. M., Genetic diversity among wild populations of almond (Amygdalous spp.) in Isfahan Province as determined by some morphological and seed storage proteins, Iranian Horti. Sci.Tech. (2002) 3: 15-28. 
